\title{
Promotion and Suppression Effects of Cationic Polymer $\varepsilon$-Poly-L-lysine on the Glucose Oxidase Reaction with Ferrocene Derivatives as Oxidants with Different Charges
}

\author{
Kohei Uematsu ${ }^{\dagger}{ }^{\text {Yuto Minami, Shu Taira, and Hajime Katano }}$ \\ Faculty of Biotechnology, Fukui Prefectural University, Eiheiji, Fukui 910-1195, Japan
}

\begin{abstract}
The effects of the cationic polymer $\varepsilon$-poly-L-lysine $(\varepsilon \mathrm{PL})$ on the enzymatic reaction rate of glucose oxidase (GOD) with ferrocene derivatives having different ionic charges have been investigated by measuring the ferrocene derivative-mediated catalytic current of oxidation by GOD. When negatively charged ferrocenes were used, the bioelectrocatalytic current, which is related to the enzymatic reaction rate, was increased by the addition of $\varepsilon$ PL. On the other hand, the reaction rates with positively charged ferrocenes were decreased by $\varepsilon \mathrm{PL}$. These promotion and suppression effects of $\varepsilon \mathrm{PL}$ were remarkable at a certain $\mathrm{pH}$ range, where $\varepsilon \mathrm{PL}$ and GOD were charged positively and negatively, respectively. Within this range, the polycationic $\varepsilon \mathrm{PL}$ would be adsorbed onto the GOD surface to enhance the electrostatic interactions of the enzyme with negatively charged substrates, and repulsion with positively charged ones. These findings should be important for practical applications of enzymes.
\end{abstract}

Keywords Reaction promotion, reaction suppression, $\varepsilon$-poly-L-lysine, glucose oxidase, ferrocene derivative

(Received October 10, 2013; Accepted November 13, 2013; Published February 10, 2014)

\section{Introduction}

The electrostatic interaction between an enzyme and a reactant should influence the enzymatic reaction rate. For example, glucose oxidase (GOD) possesses multiple negative charges at $\mathrm{pH}>\mathrm{pI}_{\mathrm{GOD}}(=4.2)^{1}, \mathrm{pI}_{\mathrm{GOD}}$ being the isoelectric point of GOD. Under these conditions, the GOD-catalyzed oxidation of glucose tended to exhibit a slower reaction rate with more negatively or fewer positively charged oxidants. ${ }^{2,3}$ In particular, ferricyanide ion $\left[\mathrm{Fe}(\mathrm{CN})_{6}\right]^{3-}$, which has been widely applied as a oxidant for a glucose biosensor based on GOD, reacts with GOD at a slower reaction rate compared to other oxidants. ${ }^{4-6}$

In a previous paper we showed that, in a neutral solution $(\mathrm{pH}=6.0)$, the GOD reaction rate with $\left[\mathrm{Fe}(\mathrm{CN})_{6}\right]^{3-}$ is increased by the addition of $\varepsilon$-poly-L-lysine $(\varepsilon \mathrm{PL})^{7,8} \quad$ Surprisingly, the bimolecular rate constant between GOD and the oxidant increased by about 10000 times. Under neutral and acidic conditions, $\varepsilon$ PL exists as a polycationic species by protonation of the $\alpha$-amino groups. ${ }^{9,10}$ The cationic polymers would adsorb onto the negatively charged surface of GOD to form polyion complex species, whose enzyme becomes more stable in water. ${ }^{11}$ Therefore, we consider that the adduction of polycationic $\varepsilon \mathrm{PL}$ reduces the negative charge of the enzyme surface, and decreases the electrostatic repulsion between $\mathrm{GOD}$ and $\left[\mathrm{Fe}(\mathrm{CN})_{6}\right]^{3-}$ to increase the reaction rate between them. It is noted that such a remarkable effect was not observed with the other cationic polymers tested, including poly(allylamine hydrochloride), ethoxylated polyethleneimine, hexadimethethrine bromide, and

† To whom correspondence should be addressed.

E-mail: kuematsu@fpu.ac.jp quarternized poly[bis(2-chloroethyl) ether-alt-1,3-bis[3(dimethylamino)propyl]urea]. These formed sediments with the $\left[\mathrm{Fe}(\mathrm{CN})_{6}\right]^{3-}$ ion.

If the promotion effect of $\varepsilon \mathrm{PL}$ can be explained by the electrostatic interaction, the effect would depend on the charge of the oxidants. When positively charged oxidants are used, $\varepsilon$ PL would decrease the rate of the GOD enzymatic reaction.

The reaction rate of redox enzymes can be analyzed by the steady-state current due to $\mathrm{M}_{\mathrm{Ox}} / \mathrm{M}_{\mathrm{Red}}$-mediated bioelectrocatalysis $\left(\mathrm{M}_{\mathrm{Ox}} \text { being the oxidant and } \mathrm{M}_{\mathrm{Red}} \text { the reduced form of } \mathrm{M}_{\mathrm{Ox}}\right)^{12,13}$ The electrochemical assay has been applied advantageously to evaluate the influences of additives on enzymes. ${ }^{11,14-17}$ In this study, the effect of $\varepsilon \mathrm{PL}$ on the GOD reaction rate was investigated electrochemically using ferrocene derivatives with different ionic charges as $\mathrm{M}_{\mathrm{Ox}}$ 's. 1,1'-Ferrocenedicarboxylic acid $\left(\left[\mathrm{Fe}(\mathrm{cp})(\mathrm{cp}-\mathrm{COOH})_{2}\right]\right)$, ferrocenecarboxylic acid $([\mathrm{Fe}(\mathrm{cp})$ $(\mathrm{cp}-\mathrm{COOH})])$, hydroxymethylferrocene $([\mathrm{Fe}(\mathrm{cp})(\mathrm{cp}-\mathrm{OH})])$, and (ferrocenylmethyl)-trimethylammonium bromide ([Fe(cp) (cp- $\left.\mathrm{CH}_{2} \mathrm{NMe}_{3}\right] \mathrm{Br}$ ) were used for the $\mathrm{M}_{\mathrm{Ox}} / \mathrm{M}_{\mathrm{Red}}$ with ionic charges of $-1 /-2,0 /-1,+1 / 0$, and $+2 /+1$, respectively. The effect of $\varepsilon \mathrm{PL}$ could be explained by the electrostatic interaction and repulsion among GOD, $\varepsilon \mathrm{PL}$, and the mediator.

\section{Experimental}

Chemicals

Glucose oxidase from Aspergillus niger was purchased from Toyobo. The concentration of GOD was determined spectrophotometrically using an absorption coefficient of $18240 \mathrm{M}^{-1} \mathrm{~cm}^{-1}$ at $460 \mathrm{~nm} .{ }^{18} \varepsilon \mathrm{PL}$ was donated by JNC Corp. The sample consisted mainly of $25-35$ L-lysine residues. ${ }^{10}$ 


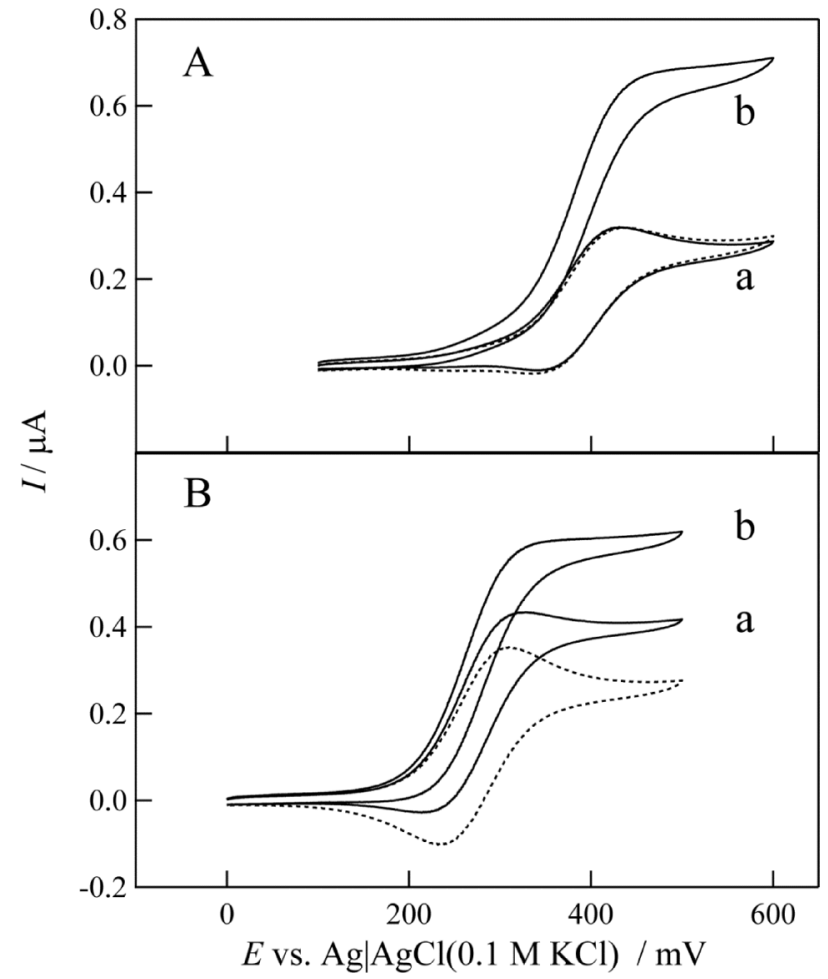

Fig. 1 Cyclic voltammograms (CVs) of MES buffer solutions (pH 6.0) containing $100 \mu \mathrm{M}(\mathrm{A})\left[\mathrm{Fe}(\mathrm{cp})(\mathrm{cp}-\mathrm{COOH})_{2}\right]$ and $(\mathrm{B})[\mathrm{Fe}(\mathrm{cp})$ (cp-COOH)], $0.30 \mu \mathrm{M}$ GOD, and $200 \mathrm{mM}$ glucose in the (a) absence and (b) presence of $20 \mathrm{mg} / \mathrm{L} \varepsilon \mathrm{PL}$ at a GC electrode. The dashed lines indicate CVs for $100 \mu \mathrm{M}$ mediators in the buffer. Scan rate, $2 \mathrm{mV} \mathrm{s}^{-1}$.

1,1'-Ferrocenedicarboxylic acid was purchased from Aldrich, and ferrocenecarboxylic acid was purchased from Wako Pure Chemical Industries. Hydroxymethylferrocene and (Ferrocenylmethyl)trimethylammonium bromide were purchased from Tokyo Chemical Industry. 2-Morpholinoethanesulfonic acid (MES) and 3-morpholinopropanesulfonic acid (MOPS) were obtained from Dojindo. They were used without further purification. Other chemicals were of reagent grade, and were used as received.

\section{Electrochemical measurements}

The enzymatic reaction was evaluated by measuring the $\mathrm{M}_{\mathrm{OX}} / \mathrm{M}_{\mathrm{Red}}$-mediated bioelectrocatalytic current for the oxidation of glucose by GOD. The electrochemical measurements were performed using a three-electrode system. A glassy carbon (GC) electrode (BAS 002012), a platinum coil, and an $\mathrm{Ag}|\mathrm{AgCl}| 0.1 \mathrm{M} \mathrm{KCl}$ electrode were used as the working electrode, the counter electrode, and the reference electrode, respectively. Cyclic voltammetry and amperometry were carried out with a laboratory-made electrochemical analyzer. An electrolysis cell with a water jacket was used to keep its temperature at $30^{\circ} \mathrm{C}$.

In the electrochemical measurements, the concentration of glucose in the test solution was $200 \mathrm{mM}$, which is much higher than the value of the Michaelis constant of glucose for GOD. ${ }^{19}$ Thus, the rate of the enzymatic reaction was independent of the glucose concentration. The test solution was buffered at $\mathrm{pH}=3.5-5.5,5.5-7.0$, and $7.0-8.0$ with $50 \mathrm{mM}$ acetate, MES, and MOPS, respectively. The measurements were performed in a deaerated solution by Ar gas.

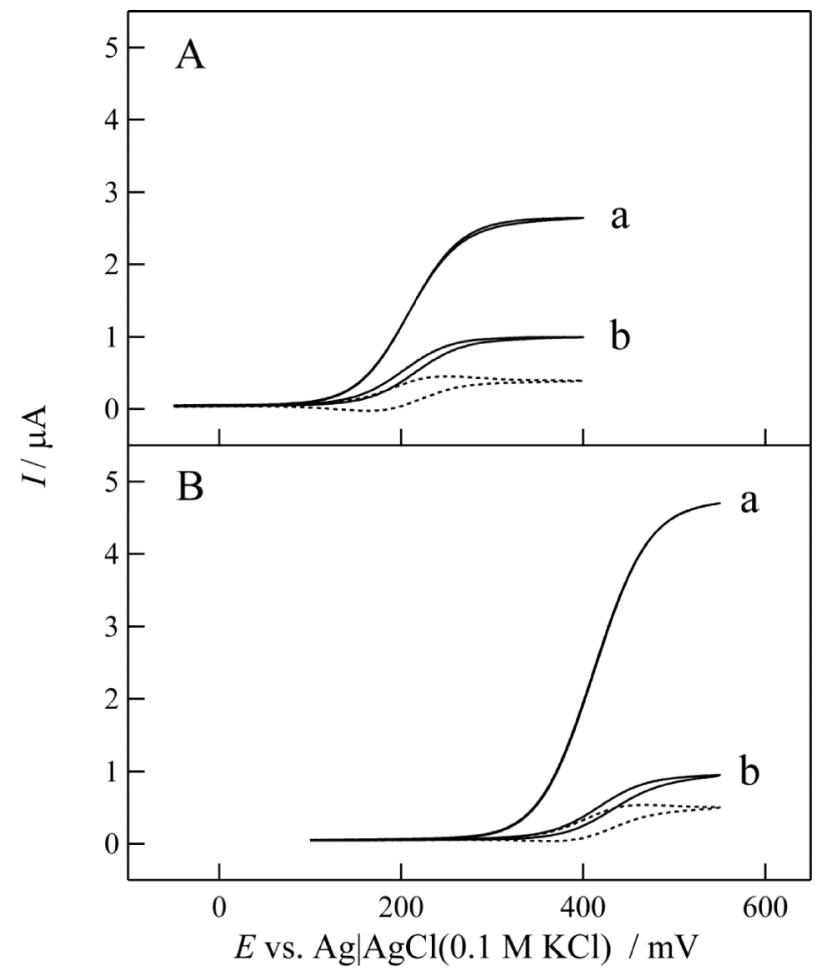

Fig. $2 \mathrm{CVs}$ of MES buffer solutions ( $\mathrm{pH}$ 6.0) containing $100 \mu \mathrm{M}$ (A) $[\mathrm{Fe}(\mathrm{cp})(\mathrm{cp}-\mathrm{OH})]$ and (B) $\left[\mathrm{Fe}(\mathrm{cp})\left(\mathrm{cp}-\mathrm{CH}_{2} \mathrm{NMe}_{3}\right)\right] \mathrm{Br}, 0.30 \mu \mathrm{M}$ GOD and $200 \mathrm{mM}$ glucose in the (a) absence and (b) presence of $20 \mathrm{mg} / \mathrm{L} \varepsilon \mathrm{PL}$ at a $\mathrm{GC}$ electrode. The dashed lines indicate $\mathrm{CVs}$ for $100 \mu \mathrm{M}$ mediators in the buffer. Scan rate, $2 \mathrm{mV} \mathrm{s}^{-1}$.

\section{Results and Discussion}

The dashed lines in Figs. 1 and 2 show the cyclic voltammograms $(\mathrm{CVs})$ of $100 \mu \mathrm{M}$ [Fe(cp)(cp-COOH $\left.)_{2}\right],\left[\mathrm{Fe}(\mathrm{cp})(\mathrm{cp}-\mathrm{COO})_{2}\right]$, $[\mathrm{Fe}(\mathrm{cp})(\mathrm{cp}-\mathrm{OH})]$, and $\left[\mathrm{Fe}(\mathrm{cp})\left(\mathrm{cp}-\mathrm{CH}_{2} \mathrm{NMe}_{3}\right)\right]^{+}$in the $50 \mathrm{mM}$ MES buffer (pH 6.0) at the scan rate of $2 \mathrm{mV} \mathrm{s}^{-1}$. The voltammograms can be assigned to reversible or quasi-reversible $\mathrm{CV}$ for one-electron transfer. The midpoint potentials of the ferrocene derivatives were in the range from 206 to $416 \mathrm{mV}$. The mediated bioelectrocatalytic current is influenced by the redox potentials of the mediators. ${ }^{20}$ However, the effect of $\varepsilon \mathrm{PL}$ can be considered to be independent of the redox potential of $\mathrm{M}_{\mathrm{Ox}} / \mathrm{M}_{\text {Red. }}$. Thus, the following experimental results are compared and discussed mainly from the perspective of the difference in the ionic charge of $\mathrm{M}_{\mathrm{Ox}}$.

Effect of $\varepsilon P L$ on the $C V$ of the mediated bioelectrocatalytic current by GOD

Curve a in Fig. 1A shows a CV for the $50 \mathrm{mM}$ MES buffer solution (pH 6.0) containing $100 \mu \mathrm{M} \quad\left[\mathrm{Fe}(\mathrm{cp})(\mathrm{cp}-\mathrm{COO})_{2}\right]$, $0.30 \mu \mathrm{M}$ GOD, and $200 \mathrm{mM}$ glucose. Although the test solution contained GOD and glucose, the CV was almost identical to that of the simple electron transfer of $\left[\mathrm{Fe}^{\mathrm{III} / \mathrm{II}}(\mathrm{cp})(\mathrm{cp}-\mathrm{COO})_{2}\right]^{-12-}$, indicating that the GOD reaction with $\left[\mathrm{Fe}^{\mathrm{III}}(\mathrm{cp})(\mathrm{cp}-\mathrm{COO})_{2}\right]^{-}$was not fast enough to confirm the $\left[\mathrm{Fe}^{\mathrm{III} / \mathrm{II}}(\mathrm{cp})(\mathrm{cp}-\mathrm{COO})_{2}\right]^{-12-}$ mediated catalytic current. At $\mathrm{pH}=6.0$ ( $\left.>\mathrm{pI}_{\mathrm{GOD}}\right), \mathrm{GOD}$ possesses multiple negative charges, and the much slower reaction rate may be explained by the electrostatic repulsion between the negatively charged GOD and $\left[\mathrm{Fe}^{\mathrm{III}}(\mathrm{cp})(\mathrm{cp}-\mathrm{COO})_{2}\right]^{-}$. Upon the addition of $20 \mathrm{mg} / \mathrm{L} \varepsilon \mathrm{PL}$, the $\mathrm{CV}$ was changed to an 


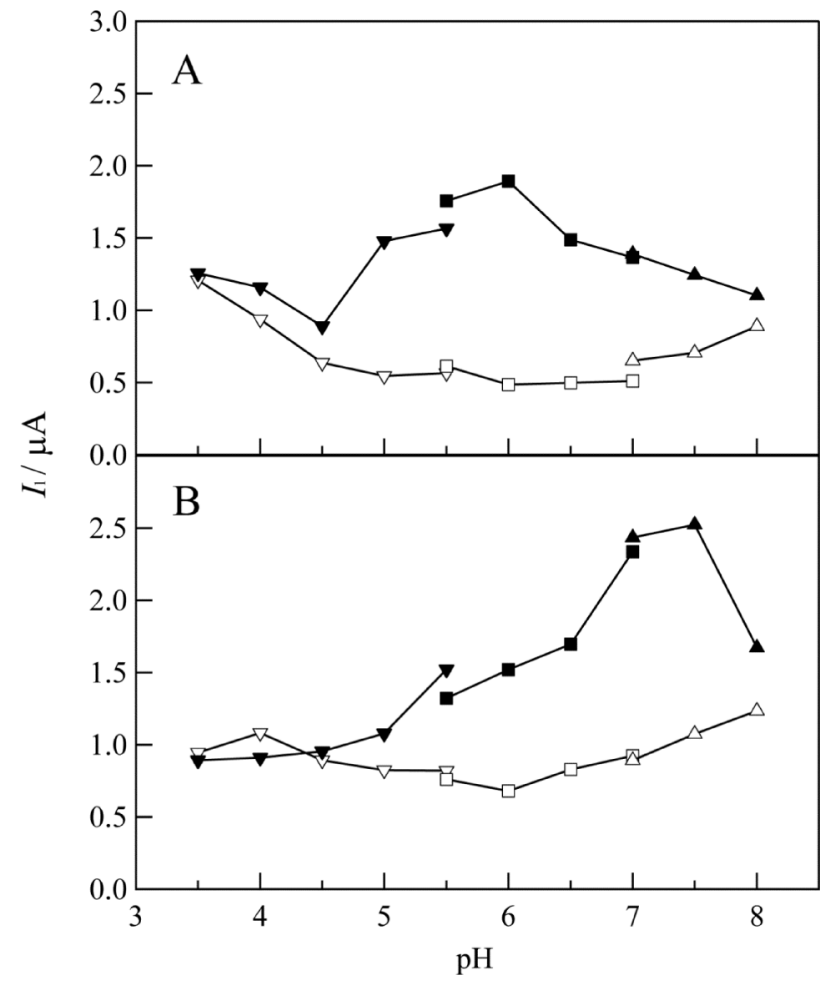

Fig. 3 Plots of $I_{1}$ vs. $\mathrm{pH}$ for (A) $\left[\mathrm{Fe}(\mathrm{cp})(\mathrm{cp}-\mathrm{COOH})_{2}\right]-$ and (B) $[\mathrm{Fe}(\mathrm{cp})(\mathrm{cp}-\mathrm{COOH})]-$ GOD-glucose solutions in the absence (open symbol) and presence (filled symbol) of $20 \mathrm{mg} / \mathrm{L} \varepsilon \mathrm{PL}$ buffered with acetate $(\nabla, \boldsymbol{\nabla})$, MES $(\square, \boldsymbol{\square})$, and MOPS $(\triangle, \mathbf{\Lambda})$. Concentration of the mediator, $c_{\mathrm{M}}=200 \mu \mathrm{M}$.

S-shaped current-potential curve with a well-developed limiting current, as shown by curve $\mathrm{b}$ of Fig. 1A, indicating that the enzymatic reaction rate with $\left[\mathrm{Fe}^{\mathrm{III}}(\mathrm{cp})(\mathrm{cp}-\mathrm{COO})_{2}\right]^{-}$was increased to confirm the catalytic current. A similar result, that is, the promotion effect of $\varepsilon \mathrm{PL}$, has been observed with the $\left[\mathrm{Fe}(\mathrm{CN})_{6}\right]^{3-14-}$-GOD-glucose system. ${ }^{7}$

Curve a in Fig. 1B shows a CV for the $[\mathrm{Fe}(\mathrm{cp})(\mathrm{cp}-\mathrm{COOH})]$ GOD-glucose solution ( $\mathrm{pH} 6.0$ ), indicating a relatively fast enzymatic reaction of the negatively charged GOD with $\left[\mathrm{Fe}^{\mathrm{III}}(\mathrm{cp})(\mathrm{cp}-\mathrm{COO})\right]^{0}$. Upon the addition of $20 \mathrm{mg} / \mathrm{L} \varepsilon \mathrm{PL}$, the $I_{1}$-value increased, as shown by curve $\mathrm{b}$ in Fig. $1 \mathrm{~B}$, indicating that $\varepsilon$ PL also promoted the GOD reaction with $\left[\mathrm{Fe}^{\mathrm{III}}(\mathrm{cp})(\mathrm{cp}-\right.$ $\mathrm{COO})]^{0}$ to some extent. It is noted that the promotion effect of $\varepsilon \mathrm{PL}$ was also observed when an anionic redox active substance, 2,2'-azino-bis(3-ethylbenzothiazoline-6-sulfonic acid), was used instead of the ferrocene derivatives.

The CVs for the $[\mathrm{Fe}(\mathrm{cp})(\mathrm{cp}-\mathrm{OH})]-$ and $[\mathrm{Fe}(\mathrm{cp})(\mathrm{cp}-$ $\mathrm{CH}_{2} \mathrm{NMe}_{3}$ ) ] -GOD-glucose solution ( $\mathrm{pH}$ 6.0) are shown by curve a in Figs. 2A and 2B, respectively. The $\mathrm{M}_{\mathrm{Ox}^{+}}{ }^{+} / \mathrm{M}_{\mathrm{Red}}{ }^{0}$ - and $\mathrm{M}_{\mathrm{Ox}}{ }^{2+} / \mathrm{M}_{\mathrm{Red}}{ }^{+}$-mediated systems without $\varepsilon \mathrm{PL}$ gave $\mathrm{S}$-shaped current-potential curves with well-defined limiting currents, indicating the fast enzymatic reaction of the negatively charged GOD with the positively charged oxidants. As shown by curve b in Figs. 2A and 2B, the $I_{1}$-value decreased in the presence of $\varepsilon$ PL. Thus, the suppression effect by $\varepsilon$ PL was observed for the GOD reaction with positively charged oxidants, as expected.

\section{Effect of $p H$}

In this section, the currents measured at constant applied potentials $(E=550,450,400$, and $550 \mathrm{mV}$ for the $[\mathrm{Fe}(\mathrm{cp})(\mathrm{cp}-$ $\left.\mathrm{COOH})_{2}\right]-, \quad[\mathrm{Fe}(\mathrm{cp})(\mathrm{cp}-\mathrm{COOH})]-, \quad[\mathrm{Fe}(\mathrm{cp})(\mathrm{cp}-\mathrm{COOH})]-, \quad$ and

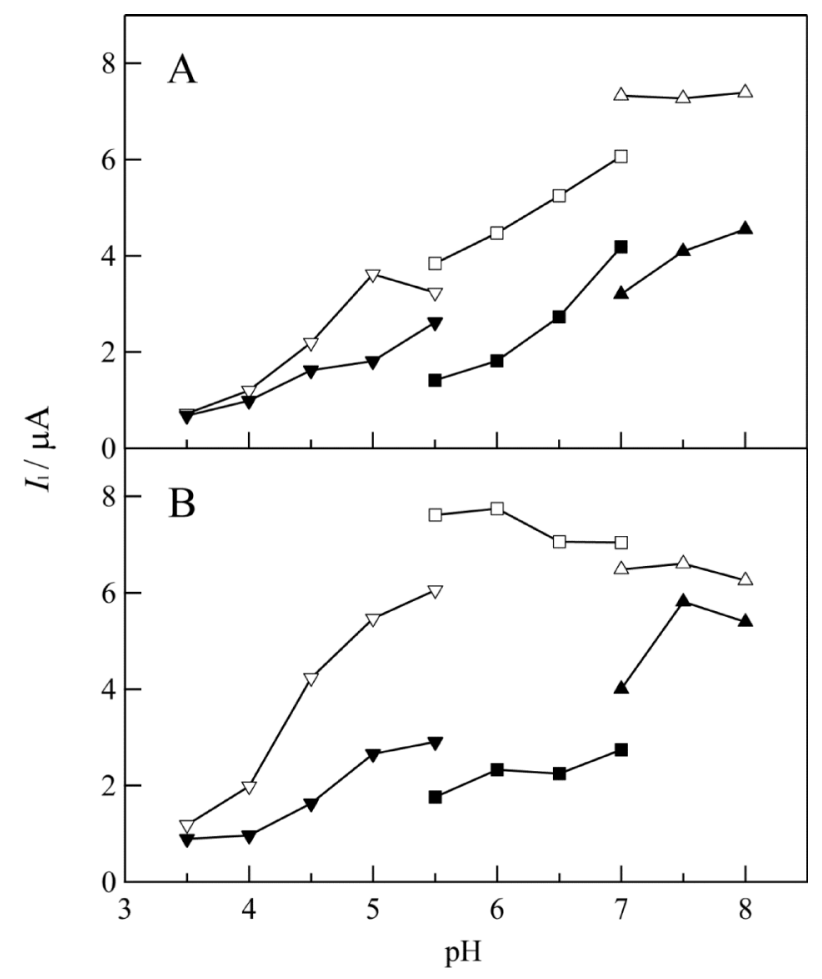

Fig. 4 Plots of $I_{1} v s$. pH for (A) [Fe(cp)(cp-OH)]- and (B) [Fe(cp) $\left.\left(\mathrm{cp}-\mathrm{CH}_{2} \mathrm{NMe}_{3}\right)\right]^{+}-$GOD-glucose solutions in the absence (open symbols) and presence (filled symbols) of $20 \mathrm{mg} / \mathrm{L} \varepsilon \mathrm{PL}$ buffered with acetate $(\nabla, \boldsymbol{\nabla})$, MES $(\square, \boldsymbol{\square})$, and MOPS $(\triangle, \mathbf{\Delta}) . c_{\mathrm{M}}=200 \mu \mathrm{M}$.

$\left[\mathrm{Fe}(\mathrm{cp})\left(\mathrm{cp}-\mathrm{CH}_{2} \mathrm{NMe}_{3}\right]^{+}\right.$-GOD-glucose solutions, respectively) in the absence and presence of $20 \mathrm{mg} / \mathrm{L} \varepsilon \mathrm{PL}$ are taken as $I_{1}$, and the $\mathrm{pH}$ dependence of $I_{1}$ is discussed. Although $\varepsilon \mathrm{PL}$ is a polyacidic base, it has been reported that the $\mathrm{pH}$ titration curve of $\varepsilon \mathrm{PL}$ is similar to that of weak monoacidic bases, and gives a clear equivalence point. ${ }^{10}$ The $\mathrm{pH}$ at the half equivalence point is determined to be 7.5, and the $\mathrm{pH}$ value is taken to be the apparent $\mathrm{p} K_{\mathrm{a}}$ of $\varepsilon \mathrm{PLH}^{\mathrm{n}+}\left(\mathrm{p} K_{\mathrm{a}, \varepsilon \mathrm{PL}}\right)$ in this paper.

Figure $3 \mathrm{~A}$ shows $I_{1}$ vs. $\mathrm{pH}$ plots for a $\left[\mathrm{Fe}(\mathrm{cp})(\mathrm{cp}-\mathrm{COOH})_{2}\right]-$ GOD-glucose solution in the absence and presence of $\varepsilon \mathrm{PL}$. The promotion effect was remarkable at $\mathrm{pI}_{\mathrm{GOD}}<\mathrm{pH}<\mathrm{p} K_{\mathrm{a}, \varepsilon \mathrm{PL}}$. Under these conditions, GOD and $\varepsilon \mathrm{PL}$ possess multiple negative and positive charges, respectively, so that the polycationic $\varepsilon \mathrm{PL}$ would be absorbed onto the GOD surface to reduce the electrostatic repulsion between GOD and $\left[\mathrm{Fe}^{\mathrm{III}}(\mathrm{cp})(\mathrm{cp}-\mathrm{COO})_{2}\right]^{-}$. The effect was not significant under the condition $\mathrm{pH}<\mathrm{pI}_{\mathrm{GOD}}$, at which GOD possesses multiple positive charges. Figure 3B shows $I_{1}$ vs. $\mathrm{pH}$ plots for the [Fe(cp)(cp-COOH)]-GOD-glucose solution. Although $\varepsilon \mathrm{PL}$ promoted the enzymatic reaction rate at $\mathrm{pI}_{\mathrm{GOD}}<\mathrm{pH}<\mathrm{p} K_{\mathrm{a}, \varepsilon \mathrm{PL}}$, the effect was less than that in the $\left[\mathrm{Fe}^{\mathrm{III} / \mathrm{II}}(\mathrm{cp}-\mathrm{COO})\right]^{-/ 2-}$-GOD-glucose system. This may be because the oxidant is charge-neutral. Figures $4 \mathrm{~A}$ and $4 \mathrm{~B}$ show plots for the $[\mathrm{Fe}(\mathrm{cp})(\mathrm{cp}-\mathrm{OH})]-$ and $\left[\mathrm{Fe}(\mathrm{cp})\left(\mathrm{cp}-\mathrm{CH}_{2} \mathrm{NMe}_{3}\right)\right] \mathrm{Br}-\mathrm{GOD}-$ glucose solutions, respectively. The $I_{1}$-values decreased upon the addition of $\varepsilon \mathrm{PL}$ at $\mathrm{pI}_{\mathrm{GOD}}<\mathrm{pH}<\mathrm{p} K_{\mathrm{a}, \varepsilon \mathrm{PL}}$, indicating the electrostatic repulsion of the positively charged surface of the $\varepsilon$ PL-GOD polyion complex with the cationic oxidants. Also, the suppression effect of $\varepsilon \mathrm{PL}$ for the $\left[\mathrm{Fe}^{\mathrm{III} / \mathrm{II}}(\mathrm{cp})(\mathrm{cp}-\right.$ $\left.\left.\mathrm{CH}_{2} \mathrm{NMe}_{3}\right)\right]^{2+/+}$-GOD-glucose system was larger than that for the $\left[\mathrm{Fe}^{\mathrm{III} / \mathrm{II}}(\mathrm{cp})(\mathrm{cp}-\mathrm{OH})\right]^{+/ 0}-\mathrm{GOD}$-glucose system.

The $I_{1}$-value seemed to vary to some extent with the kind of buffer component, as can be seen in the discontinuities at $\mathrm{pH} 5.5$ 


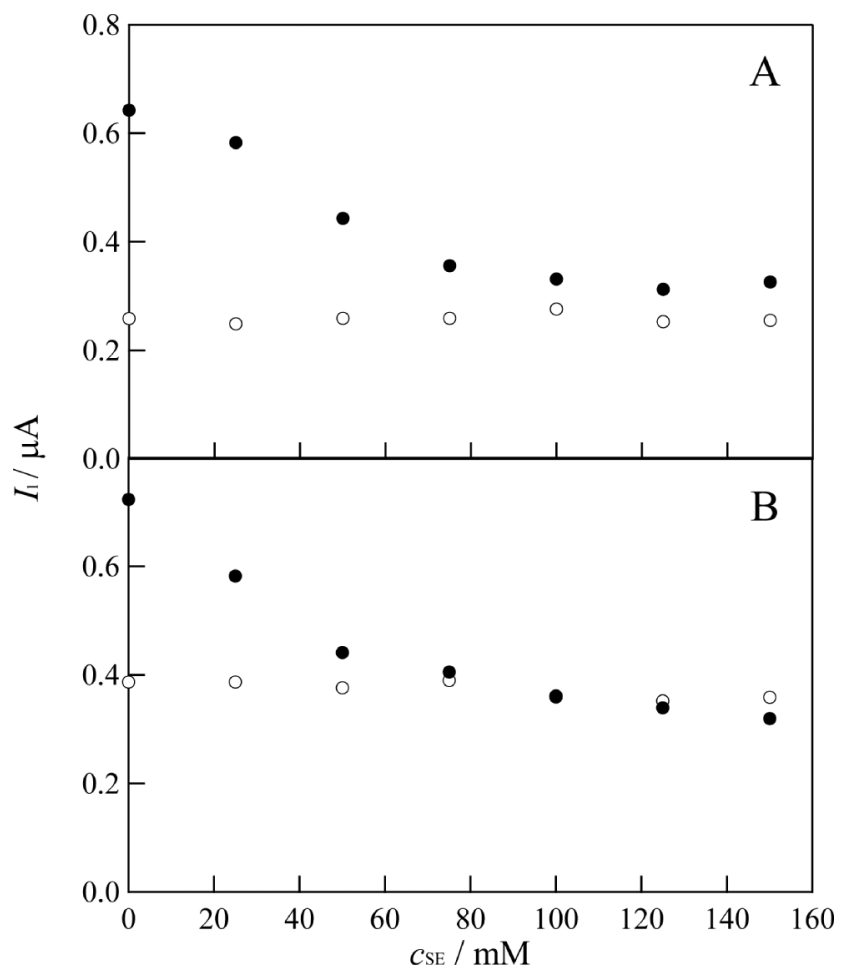

Fig. 5 Plots of $I_{1} v s$. the concentration of $\mathrm{KNO}_{3}, c_{\mathrm{SE}}$, for (A) $[\mathrm{Fe}(\mathrm{cp})$ $\left.(\mathrm{cp}-\mathrm{COOH})_{2}\right]-$ and $(\mathrm{B})[\mathrm{Fe}(\mathrm{cp})(\mathrm{cp}-\mathrm{COOH})]-G O D$-glucose solutions $(\mathrm{pH} 6.0)$ in the absence $(\bigcirc)$ and presence $(\bullet)$ of $20 \mathrm{mg} / \mathrm{L} \varepsilon \mathrm{PL} . \quad c_{\mathrm{M}}=$ $100 \mu \mathrm{M}$.

and 7.0. However, these discontinuities may be explained mainly by the difference in the ionic strength of the buffer solutions, as described below.

\section{Effect of the electrolyte}

Figures 5 and 6 show plots of $I_{1}$ for the mediator-GOD-glucose solution ( $\mathrm{pH}$ 6.0) without and with $\varepsilon \mathrm{PL}$ against the concentration of the supporting electrolyte $\mathrm{KNO}_{3}, c_{\mathrm{SE}}$. The $I_{\mathrm{l}}$-values for the $\left[\mathrm{Fe}^{\mathrm{III} / \mathrm{II}}(\mathrm{cp})(\mathrm{cp}-\mathrm{COO})_{2}\right]^{-/ 2-}$ and $\left[\mathrm{Fe}^{\mathrm{III} / \mathrm{II}}(\mathrm{cp})(\mathrm{cp}-\mathrm{COO})\right]^{0 /-}-\mathrm{GOD}-$ glucose systems without $\varepsilon \mathrm{PL}$ did not change with $c_{\mathrm{SE}}$, as shown by the open circles in Figs. 5A and 5B, respectively. However, the $I_{1}$-values with $\varepsilon \mathrm{PL}$ decreased with $c_{\mathrm{SE}}$, as shown by the filled circles in the figures, suggesting a reduction of the electrostatic interaction between the positively charged polyion complex of GOD and the negatively charged oxidant.

On the other hand, the $I_{1}$-values for the $\left[\mathrm{Fe}^{\mathrm{III} / \mathrm{II}}(\mathrm{cp})(\mathrm{cp}-\mathrm{OH})\right]^{+/ 0_{-}}$ and $\left[\mathrm{Fe}^{\mathrm{III} / \mathrm{II}}(\mathrm{cp})\left(\mathrm{cp}-\mathrm{CH}_{2} \mathrm{NMe}_{3}\right)\right]^{2+/+}-\mathrm{GOD}$-glucose system with $\varepsilon \mathrm{PL}$ did not change significantly with $c_{\mathrm{SE}}$, as shown in Figs. $6 \mathrm{~A}$ and $6 \mathrm{~B}$. Also, the $I_{1}$-values without $\varepsilon \mathrm{PL}$ decreased with $c_{\mathrm{SE}}$, suggesting again the reduction of electrostatic interaction between the negatively charged GOD and the positively charged oxidant. The ionic activities of the multiply charged GOD and the polyion complex may be reduced significantly in high-ionicstrength solutions.

\section{Interaction between $\varepsilon P L$ and a mediator}

In the previous paper, we showed that the polycationic $\varepsilon \mathrm{PL}$ also associates with $\left[\mathrm{Fe}(\mathrm{CN})_{6}\right]^{4-13-}$ to form a polyion complex. ${ }^{7}$ This formation can be observed from the change in $\mathrm{CV}$ for the electron transfer of the mediator at a GC electrode. ${ }^{21}$ Figure 7 shows the $\mathrm{CVs}$ of $100 \mu \mathrm{M}\left[\mathrm{Fe}(\mathrm{cp})(\mathrm{cp}-\mathrm{COOH})_{2}\right]$ in a $50-\mathrm{mM}$ MES buffer solution ( $\mathrm{pH}$ 6.0) with different concentrations of

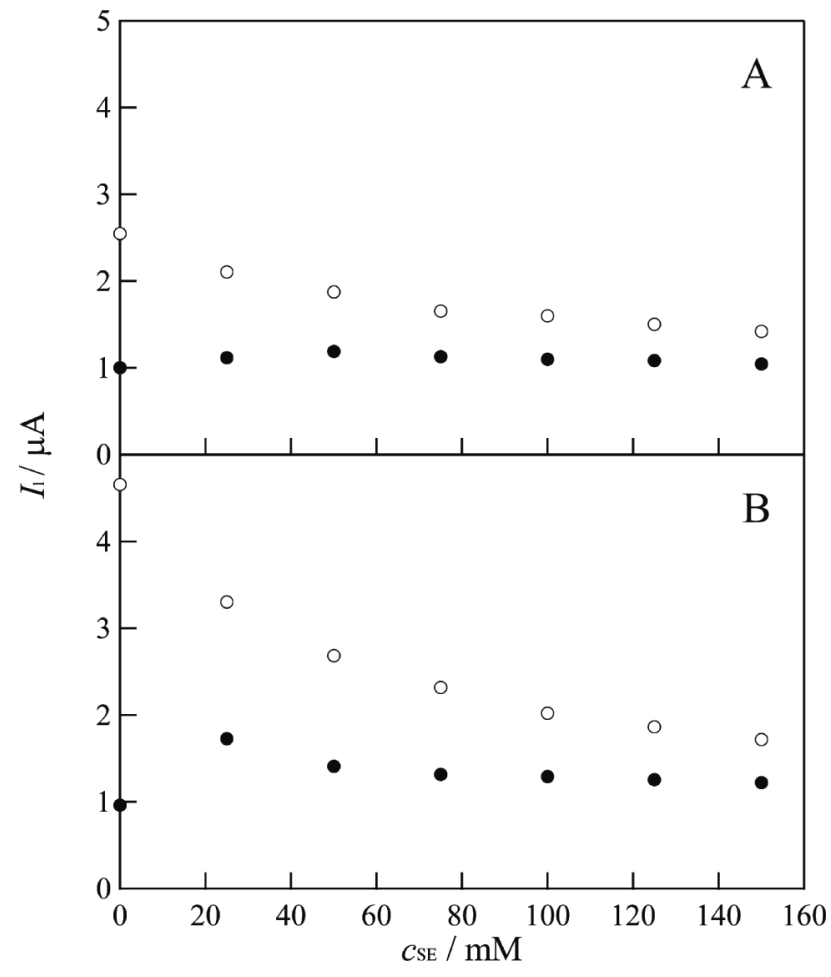

Fig. 6 Plots of $I_{1} v s$. $c_{\mathrm{SE}}$ for (A) $[\mathrm{Fe}(\mathrm{cp})(\mathrm{cp}-\mathrm{OH})]-$ and (B) $[\mathrm{Fe}(\mathrm{cp})$ $\left.\left(\mathrm{cp}-\mathrm{CH}_{2} \mathrm{NMe}_{3}\right)\right]^{+}-\mathrm{GOD}$ - glucose solutions $(\mathrm{pH} 6.0)$ in the absence $(\bigcirc)$ and presence $(\bullet)$ of $20 \mathrm{mg} / \mathrm{L} \varepsilon \mathrm{PL} . \quad c_{\mathrm{M}}=100 \mu \mathrm{M}$.

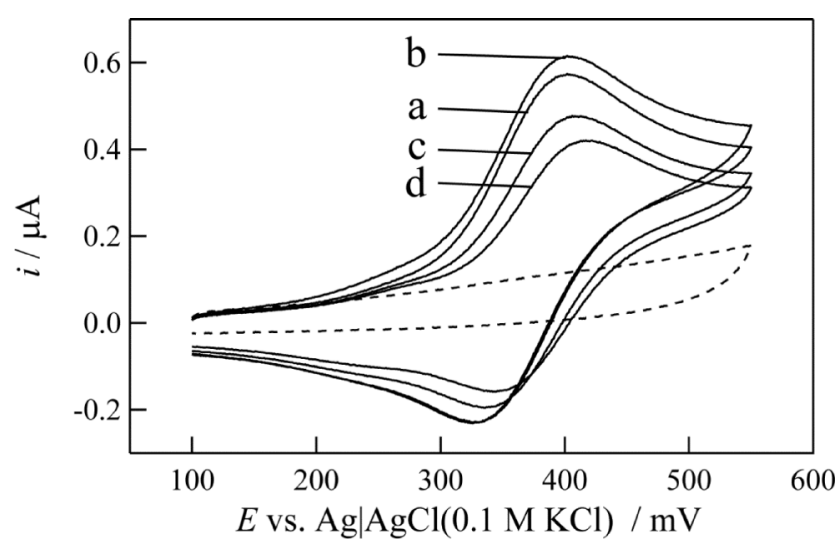

Fig. $7 \mathrm{CVs}$ of $100 \mu \mathrm{M}\left[\mathrm{Fe}(\mathrm{cp})(\mathrm{cp}-\mathrm{COOH})_{2}\right]$ in $50 \mathrm{mM}$ MES buffer (pH 6.0) with different concentrations of $\varepsilon \mathrm{PL}, c_{\mathrm{PL}}=$ (a) 0 , (b) 20, (c) 300 , and (d) $1000 \mathrm{mg} / \mathrm{L}$. Scan rate, $20 \mathrm{mV} \mathrm{s}^{-1}$.

$\varepsilon \mathrm{PL}\left(c_{\mathrm{PL}}\right)$. When $c_{\mathrm{PL}}>100 \mathrm{mg} / \mathrm{L}$, the cathodic and anodic peak current decreased, and the midpoint potential shifted to more positive potentials, indicating the formation of the polyion complex of $\varepsilon \mathrm{PL}$ with $\left[\mathrm{Fe}^{\mathrm{III} / \mathrm{II}}(\mathrm{cp})(\mathrm{cp}-\mathrm{COO})_{2}\right]^{-12-}$. When $c_{\mathrm{PL}}=20 \mathrm{mg} / \mathrm{L}$ (curve $\mathrm{b}$ ), at which the promotion effect was remarkable, the $\mathrm{CV}$ did not differ significantly from that without $\varepsilon \mathrm{PL}$ (curve a). Under the solution condition, the polyion complex of $\varepsilon \mathrm{PL}$ with $\left[\mathrm{Fe}^{\mathrm{III} / \mathrm{II}}(\mathrm{cp})(\mathrm{cp}-\mathrm{COO})_{2}\right]^{-/ 2-}$ may not form quantitatively. Therefore, the promotion effect of $\varepsilon \mathrm{PL}$ would be mainly due to the adduction of $\varepsilon \mathrm{PL}$ to GOD. For the other mediator, such changes of $\mathrm{CV}$ by $\varepsilon \mathrm{PL}$ were not observed, indicating that those mediators did not interact with $\varepsilon \mathrm{PL}$ significantly. 


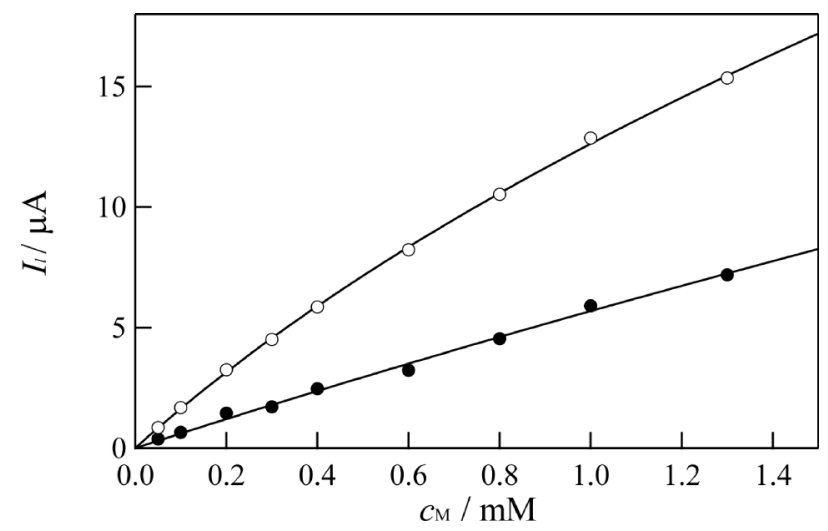

Fig. 8 Plots of $I_{1}$ vs. $c_{\mathrm{M}}$ for $[\mathrm{Fe}(\mathrm{cp})(\mathrm{cp}-\mathrm{OH})]-G O D-$ glucose solutions $(\mathrm{pH}$ 6.0) in the absence $(\bigcirc)$ and presence $(\bullet)$ of $20 \mathrm{mg} / \mathrm{L} \varepsilon \mathrm{PL}$. Concentration of GOD, $0.13 \mu \mathrm{M}$. Solid lines, regression curves using the analytical equation of $I_{1}$.

Table $1 k_{\text {cat }} / K_{\mathrm{M}}$ values for the GOD enzymatic reaction with ferrocene derivatives at $\mathrm{pH} 6.0$

\begin{tabular}{lcc}
\hline \multicolumn{1}{c}{ Mediator (as $\left.\mathrm{M}_{\mathrm{Ox}}\right)$} & $\begin{array}{c}k_{\text {cat }} K_{\mathrm{M}}{ }^{-1} / \mathrm{dm}^{3} \mathrm{~mol}^{-1} \mathrm{~s}^{-1} \\
\text { without } \varepsilon \mathrm{PL}\end{array}$ & $\begin{array}{c}k_{\text {cat }} K_{\mathrm{M}^{-1}} / \mathrm{dm}^{3} \mathrm{~mol}^{-1} \mathrm{~s}^{-1} \\
\text { with } \varepsilon \mathrm{PL}\end{array}$ \\
\hline$\left[\mathrm{Fe}(\mathrm{CN})_{6}\right]^{3-}($ Ref. 7$)$ & 14 & $1.4 \times 10^{5}$ \\
{$\left[\mathrm{Fe}^{\mathrm{III}}(\mathrm{cp})(\mathrm{cp}-\mathrm{COO})_{2}\right]^{-}$} & n.d. & $9 \times 10^{5}$ \\
{$\left[\mathrm{Fe}^{\mathrm{III}}(\mathrm{cp})(\mathrm{cp}-\mathrm{COO})\right]^{0}$} & $2 \times 10^{5}$ & $4 \times 10^{5}$ \\
{$\left[\mathrm{Fe}^{\mathrm{II}}(\mathrm{cp})(\mathrm{cp}-\mathrm{OH})\right]^{+}$} & $5 \times 10^{6}$ & $8 \times 10^{5}$ \\
{$\left[\mathrm{Fe}(\mathrm{cp})^{\mathrm{II}}\left(\mathrm{cp}-\mathrm{CH}_{2} \mathrm{NMe}_{3}\right)\right]^{2+}$} & $7 \times 10^{7}$ & $1 \times 10^{6}$ \\
\hline
\end{tabular}

n.d., cannot be determined.

\section{Bimolecular rate constants}

To evaluate the effect of $\varepsilon \mathrm{PL}$ on the GOD enzymatic reaction quantitatively, the dependence of $I_{1}$ on the concentration of the mediator, $c_{\mathrm{M}}$, was investigated. Figure 8 shows plots of $I_{1} v s . c_{\mathrm{M}}$ in the absence and presence of $\varepsilon \mathrm{PL}$ for the $[\mathrm{Fe}(\mathrm{cp})(\mathrm{cp}-\mathrm{OH})]-$ GOD-glucose solution ( $\mathrm{pH} \mathrm{6.0)}$ as an example. Using the analytical equation of $I_{1}$, the catalytic constant, $k_{\text {cat }}$, and the Michaelis constant of the mediator, $K_{\mathrm{M}}$, would be determined. ${ }^{13}$ However, because of the poor solubility of ferrocene derivatives, the $I_{1} v s . c_{\mathrm{M}}$ plot could not be obtained in a $c_{\mathrm{M}}$ range sufficient to determine $k_{\text {cat }}$ and $K_{\mathrm{M}}$. Here, only the bimolecular rate constant between GOD and the mediator $\left(k_{\mathrm{cat}} / K_{\mathrm{M}}\right)$ was determined; it is summarized in Table 1 together with the rate constants determined for the reaction with $\left[\mathrm{Fe}(\mathrm{CN})_{6}\right]^{3-} .7$ The increment and decrement in $k_{\text {cat }} / K_{\mathrm{M}}$ by $\varepsilon \mathrm{PL}$; that is, the promotion and suppression effects, tend to increase as the numbers of negative and positive charges of $\mathrm{M}_{\mathrm{Ox}}$, respectively, increase. enzymatic reaction can be explained simply by the electrostatic interaction among GOD, $\varepsilon$ PL, and the mediator. These effects should be important for practical applications of enzymes, and the present findings are useful for selecting additives for enzymatic reaction mixtures. Further investigations using other cationic polymers and enzymes are in progress.

\section{References}

1. R. Wilson and A. P. F. Turner, Biosens. Bioelectron., 1992, 7, 165.

2. E. Liaudet, F. Battaglini, and E. J. Calvo, J. Electroanal. Chem., 1990, 293, 55.

3. D. M. Fraser, S. M. Zakeeruddin, and M. Gratzel, J. Electroanal. Chem., 1993, 359, 125.

4. S. Ikeda, T. Yoshioka, and S. Nankai, Electrochemistry, 1995, 12, 1145.

5. A. E. G. Cass, G. Davis, G. D. Francis, H. A. O. Hill, W. J. Aston, I. J. Higgins, E. V. Plotkin, L. D. L. Scott, and A. P. F. Turner, Anal. Chem., 1984, 56, 667.

6. J. J. Kulys and N. K. Cenas, Biochim. Biophys. Acta, 1983, 744, 57.

7. K. Uematsu, M. Yamasaki, T. Hibi, and H. Katano, Anal. Sci., 2012, 28, 657.

8. H. Katano, K. Uematsu, C. Maruyama, and Y. Hamano, Anal. Sci., 2014, 30, 17.

9. S. Shima and H. Sakai, Agric. Biol. Chem., 1981, 45, 2503.

10. H. Katano, T. Yoneoka, N. Kito, C. Maruyama, and Y. Hamano, Anal. Sci., 2012, 28, 1153.

11. H. Katano, Y. Sugimoto, K. Uematsu, and T. Hibi, Anal. Sci., 2011, 27, 979.

12. T. Ohgaru, H. Tatsumi, K. Kano, and T. Ikeda, J. Electroanal. Chem., 2001, 496, 37.

13. R. Matsumoto, K. Kano, and T. Ikeda, J. Electroanal. Chem., 2002, 535, 37.

14. H. Katano, H. Tatsumi, T. Hibi, T. Ikeda, and T. Tsukatani, Anal. Sci., 2008, 24, 1421.

15. H. Katano, K. Uematsu, T. Hibi, T. Ikeda, and T. Tsukatani, Anal. Sci., 2009, 25, 1077.

16. T. Ikeda, K. Uematsu, H. Ma, H. Katano, and T. Hibi, Anal. Sci., 2009, 25, 1283.

17. K. Uematsu and H. Katano, Anal. Sci., 2013, 29, 25.

18. "Biochemical Data Book, vol. 1 (in Japanese)", ed. Japan Biochemical Society, 1979, Tokyo Kagaku Dojin, Tokyo.

19. B. E. P. Swoboda and V. Massay, J. Biol. Chem., 1965, 240, 2209.

20. Y. Ogino, K. Takagi, K. Kano, and T. Ikeda, J. Electroanal. Chem., 1995, 396, 517.

21. H. Katano, H. Tatsumi, T. Hibi, T. Ikeda, and T. Tsukatani, Anal. Sci., 2008, 24, 1415.

\section{Conclusions}

The promotion and suppression effects of $\varepsilon \mathrm{PL}$ on the GOD 